\title{
Economic Aspects of Milk Production in Organic and Conventional Specialised Dairy Farms in Poland
}

\author{
By Marcin Żekało*
}

In the dairy sector in Poland, the processes of concentration lower the unit costs of production and increase profitability and competitiveness of milk production. A large part of market-oriented dairy farms still maintain a small herd of dairy cattle, which often leads farmers to more extensive milk production. This may result in lower milk yield, leads to the reduction of the direct costs of production. In such case, it may be justified to participate in the system of organic farming, and there is still the possibility to obtain additional financial support. The purpose of this article is to present the economic situation of organic milk production and its profitability. It is also an attempt to refer to results obtained in conventional dairy farms. Accounting data for 'dairy cows' activity were processed according to the rules of the Agricultural Products Data Collection System (AGROKOSZTY). The surveyed farms (organic and conventional ones) were selected from a representative sample of Polish FADN. Under the AGROKOSZTY system, the methodology used for calculating the gross margin was consistent with EU rules. Calculating the gross margin gives a full insight into actual direct costs and helps to compare the competitiveness of milk production in organic farms. The income from 'dairy cows' activity account is based on the Polish FADN information collected from the same farm. The income from milk production in the surveyed organic farms largely depended on lower total costs, but was also supported by higher subsidies than in conventional farms. The results indicate that the total costs of production were $42.3 \%$ lower than in conventional farms. However, the profitability of milk production in organic farms was lower due to the value of production being $39.8 \%$ lower.

The dairy sector in Poland has changed significantly, and farms involved in commercial milk production often had to undergo substantial modernisation. Increasingly, dairy farms in Poland exhibit greater specialisation and concentration processes. Due to the growing scale of commercial production, the number of dairy farms has decreased. It is estimated that between 2004 and

*Assistant, Institute of Agricultural and Food Economics - National Research Institute, Warsaw, Poland. 
2012, the number of dairy farms that supply raw milk to the market dropped by ca. $60 \%$. Over that period, dairy herds were reduced significantly, and the decrease in the number of cows amounted to $13.9 \%$. The smaller number of dairy cows is partly offset by the regular growth of their milk yield. Between 2004 and 2012, the average milk yield at individual farms in Poland increased by $24.6 \%$ (Figure 1 ).

Figure 1. Number of Dairy Cows and Milk Yield in Individual Farms between 2004 and 2012 in Poland

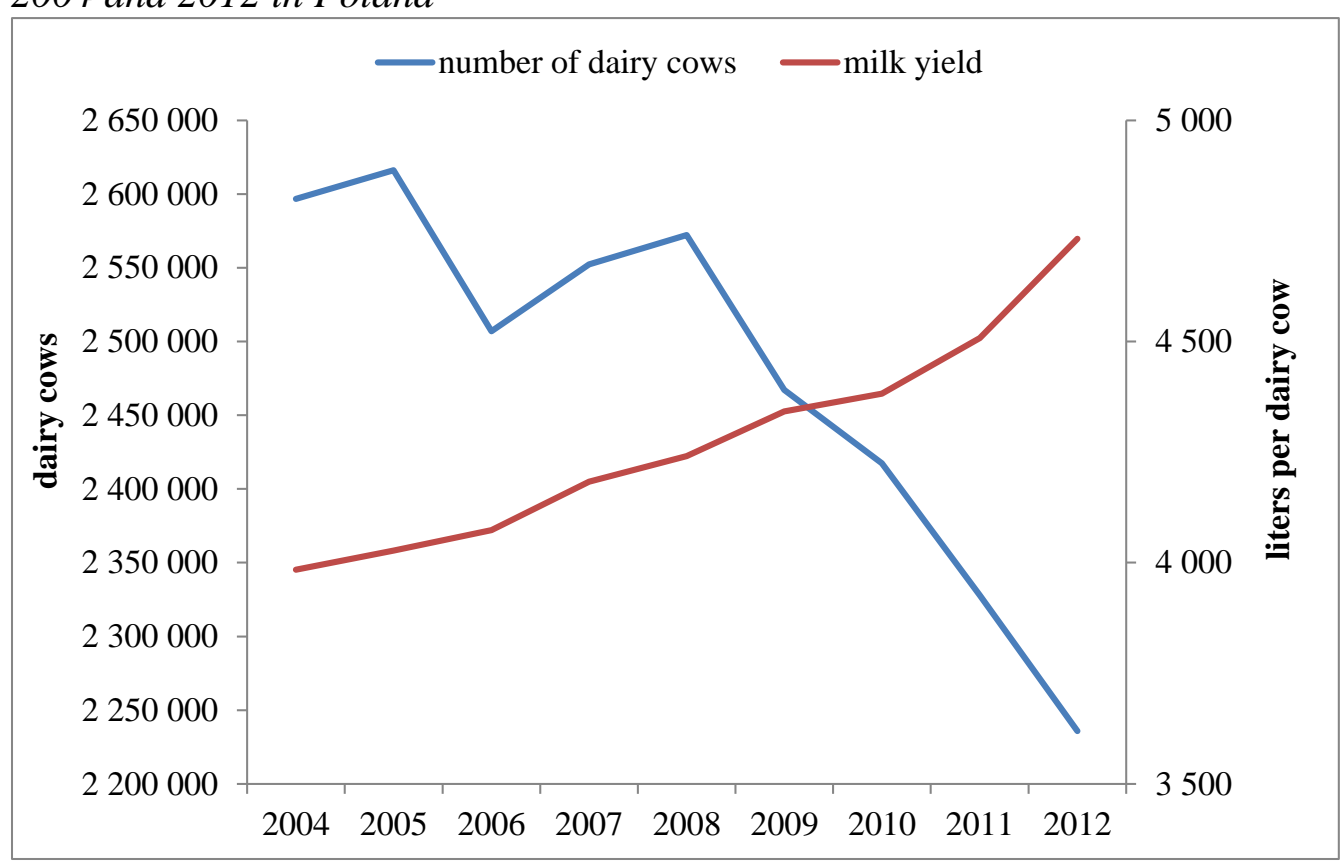

However, a significant number of farms still keep small dairy herds (in 2010 , ca. 55\% of commercial dairy farms kept less than 10 dairy cows). This situation creates conditions to conduct less intensive milk production at such farms, focusing mainly on the use of the farm's own resources, which is economically justified by lower production costs. Studies show that an increase in the profitability of specialised dairy farms depends on the possibilities to reduce unit production costs (Mańko, 2007). Conventional farms may decrease the expenses incurred for production by, for instance, using lower amounts of mineral fertilisers and protective products, and making smaller investments on the farm. Farms that already conduct extensive production (e.g. organic farms) are less dependent on purchasing goods and services. They pursue production mainly on the basis of the farm's own resources, thus incurring lower costs, but as a result they may have lower production output and reduction of the number of dairy cows in the herds. In the case of farms that pursue extensive dairy cattle production, the milk yields are lower (even $30 \%$ less than at conventional farms), but it should be indicated that the period of using the cows is longer, which translates directly into lower costs of herd replacement (Żukowski, 2009). 
Organic farms that produce milk and keep dairy cows have to meet relevant criteria and standards, which mainly relate to the quality of feed and animal welfare. Feed must come from an organic farm, preferably from the farmer's own holding, and it is necessary to provide an appropriate forage area. The most common are pasture lands, where roughage (green fodder, dried fodder or silage) is obtained. An increasingly frequent observation is that animal production based on permanent grasslands is beneficial for both the natural environment and for the perspective of production economics (Radkowska, 2012). Purchased organic feed is relatively expensive and its availability on the market is still very limited. The existing restrictions on animal feeding prohibit the use of industrial concentrates and complete feed. There are also specific guidelines on the technical and sanitary conditions of dairy cows breeding. However, problems often occur as regards the adjustment of the existing farm buildings, in particular at small farms, which is mainly related to the lack of economic justification for the new investments. Thus, exceptions are possible, e.g. permission to keep animals tied-up in a cow shed. The choice of breeds of dairy cows also plays a significant role in optimising organic milk production, in particular as regards maintaining the good health of the herd, because antibiotics are not used in organic farming.

The main product of the type of activity of 'dairy cows' is milk (and to a small extent, weaned calves and cull dairy cows), and an important factor that influences the obtained production value is the sales price of raw milk. It depends on the supply of products to the market and on the direction of outlet. When sold directly at the farm or in an open-air market, organic products obtain similar or slightly higher prices as compared to products from conventional farms. Reports from the European market point to a difference ranging from $10 \%$ to $40 \%$ (Offermann, Nieberg, 2000). But usually, when selling raw milk for processing, organic farmers may expect higher prices only in the case of organic processing - then raw milk quality is rewarded by a higher farm-gate milk price. In other instances, milk produced on organic farms goes to conventional dairies, where producers get the same or even lower prices (which results from relatively small batches of raw milk) than conventional farmers.

Farmers who undertake organic farming may count on support in the form of subsidies targeted at that sector, which significantly influence the level of income obtained from agricultural activity. In the case of the type of activity of 'dairy cows' subsidies are calculated per forage area and include supplementary payments, agri-environmental payments and payments per animals. Additionally, it is possible to obtain financial support from programmes of conservation of genetic resources of animals, all the more so as dairy breeds covered by the programme are preferred in extensive milk production systems, particularly in organic farming. One example of such dairy breed is the Polish Red cattle (reared mainly in southern Poland), characterised by features that facilitate organic farming, e.g. the animals' high resistance and very good health, their longevity and very high fertility. 
According to research conducted by the Institute of Agricultural and Food Economics - National Research Institute (IAFE-NRI) under the AGROKOSZTY system, agricultural production carried out at organic farms is associated with a low level (compared to conventional farms) of direct costs. It is largely due to this fact that organic farms are able to achieve good results in terms of the gross margin, despite significantly weaker output.

The aim of this study is to illustrate milk production and the economic situation of organic dairy farms, and the profitability of milk production pursued by them, as well as to make an attempt at referring to the results obtained by conventional dairy farms specialised in milk production.

\section{Materials and Methods}

The analysis was based on actual accounting data collected in 2012 at conventional and organic farms which kept dairy cows. The farms to be studied were taken from a sample of farms that keep agricultural accounts under the Polish FADN; these were primarily market-oriented entities, economically stronger than the average farm in the country. The researched group of farms that keep dairy cows was broken down by agricultural type TF8 (based on the typology of farms in the FADN system); units that specialise in milk production were selected (type of farming: dairy cows). The type of farming is defined on the basis of the contribution of individual types of agricultural activities to the total Standard Output value of a farm, and it reflects the pursued system of production (FADN Team 2012). The selected organic farms were located in two regions: Mazowsze and Podlasie, and Małopolska and Pogórze, i.e. regions where milk production at organic farms is the most significant on the national scale (according to the data of the Agricultural and Food Quality Inspection, in 2009 it amounted to nearly 52\% of the national amount of organic production of raw milk). In the same agricultural regions, conventional farms that specialise in milk production were selected in order to keep similar production conditions.

Accounting data was collected according to the methodological assumptions of the Agricultural Products Data Collection System AGROKOSZTY. For the researched type of activity 'dairy cows', the methodology of calculating the gross margin was used (Augustyńska-Grzymek et al., 2000). It is the first income category, calculated by deducting the direct costs incurred for producing the output from production value. In the case of dairy cows, the production value is calculated per one dairy cow. In estimating the price of production value, the average annual sales prices are used - the sales price of milk, the price of weaned calves and the price of culled dairy cows. The production value does not take into account the value of manure and slurry, which are produced at the farm. For dairy cows, direct costs include: livestock replacement, feedingstuff purchased and produced on the farm, rents paid for using forage area for less than 1 year, animal insurance, medicines and veterinary measures as well as specialised costs (including specialised 
expenses, services and employment of staff for specialised works). Moreover, a register of own and hired labour spent on works related to the type of activity 'dairy cows' is kept. Maintaining an account for income allows for obtaining information regarding activity (e.g. indirect costs, forage area, annual average number of animals), which comes from accounting data collected on the same farm for the Polish FADN system.

The pattern for calculating the categories of income for agricultural production activities is as follows:

Production value

- Direct costs

$=$ Gross margin without subsidies

- Total indirect costs (actual indirect costs, depreciation, cost of external factors)

= Income from activity without subsidies

+ Subsidies

$=$ Income from activity

On the basis of the obtained accounting data, it is also possible to define the profitability of production as a ratio of production value to total costs, in percent (Skarżyńska, 2011). In order to assess the efficiency of the incurred expenses, basic economic efficiency measures were applied.

Subsidies per forage area were recognized as support to farmers' income from the type of activity of 'dairy cows'. The calculation of income from activity includes subsidies that have a direct impact on the discussed production activity, i.e. supplementary area payment for basic crops, the payment for animals, and in the case of organic farms - agri-environmental payments.

\section{Results}

The studied sample included 13 organic farms and 72 conventional farms; both groups of farms specialise in dairy cow (TF8 type: dairy cows). The average area of agricultural land of the organic farms under analysis was $16.3 \%$ smaller than that of conventional farms, while the area of permanent grasslands was $84.2 \%$ greater. The annual average number of cows at organic farms was $30.3 \%$ smaller than at conventional farms, and milk yields of cows were $39.6 \%$ lower (Table 1). 
Table 1. General Information on the Studied Groups of Conventional and Organic Specialised Dairy Farms in 2012

\begin{tabular}{llcc}
\hline \multicolumn{1}{c}{ Specification } & & \multicolumn{2}{c}{ Specialised dairy farms } \\
\cline { 3 - 4 } Number of surveyed farms & & conventional & organic \\
\hline Utilised agricultural area & (ha) & 72 & 13 \\
Permanent grasslands & (ha) & 34.2 & 28.6 \\
Forage area & (ha per cow) & 11.4 & 0.93 \\
Annual average number of dairy cows & (heads per farm) & 21.0 \\
Milk yield & (liters per cow) & 5923 & 16 \\
Annual selling milk price & (EUR per liter) & 0.30 & 3580 \\
Total labour input & (hours per cow) & 124 & 0.27 \\
\hline
\end{tabular}

Analysing the economic results at the level of the gross margin from milk production in the selected groups, it may be stated that in both cases activity was profitable, but milk production at conventional farms proved to be more profitable. On average, the gross margin without subsidies in those units was $36.9 \%$ higher as compared to organic farms. This was concluded mainly from the significantly higher (by $66.1 \%$ ) production value in the group of conventional farms. However, it should be noted that the level of direct costs of milk production at organic farms was much lower. This refers especially to the total costs of feedingstuff, which at organic farms were 3.5 times lower than at conventional farms, mainly due to the cost of purchased feedingstuff being 12 times lower and the cost of unmarketable feedingstuff produced on the farm being 6.4 times lower. The cost of livestock replacement in the group of organic farms was also considerably lower - these costs were $35.9 \%$ lower than at conventional farms. In the category of other direct costs (expenses on rent for the use of forage area; veterinary medicines, measures and services, specialised costs related to dairy cattle keeping) farmers from both groups spent similar amounts - Figure 2 .

Figure 2. Direct Costs of Milk Production (Per Dairy Cow) in the Studied Groups of Conventional and Organic Specialised Dairy Farms in 2012.

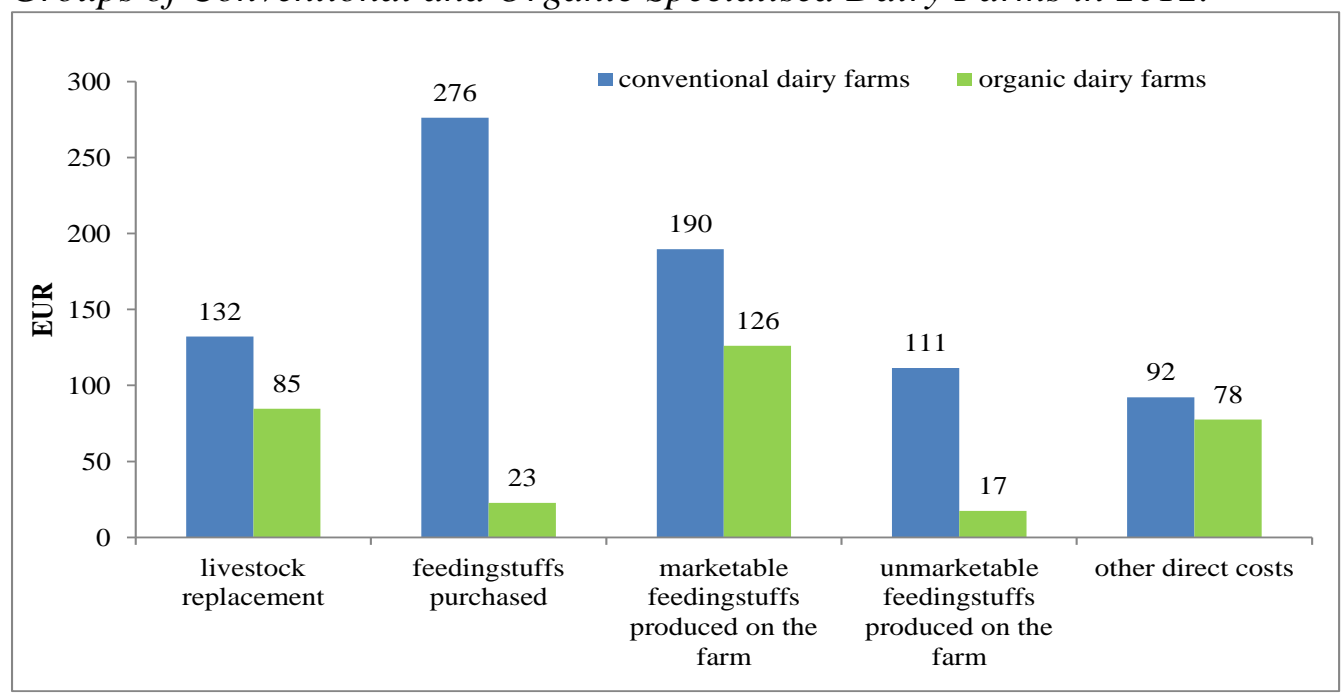


Total indirect costs (actual indirect costs, depreciation and cost of external factors) in both of the groups under analysis were at a similar level; at organic farms they were only $4.7 \%$ lower than in the case of conventional farms. Despite the significantly lower total costs (both direct and indirect), income from activity without subsidies in the group of organic farms turned out to be $54.9 \%$ lower than in the group of conventional farms. After adding the subsidies, the difference in the income from the 'dairy cows' activity decreased, but the result of organic farms was still worse by $45.9 \%$ - Figure 3 .

Subsidies per forage area had a much greater impact on the income situation of milk production in the group of organic farms than in the group of conventional ones. In the income from activity of the studied organic farms, the average share of these subsidies amounted to $21.7 \%$, while in the case of conventional farms the share was at the level of $6.1 \%$. This comes from the fact that subsidies for farmers who operate organic farms were nearly twice as high, hence the role of this form of support was evident, the more so as income from activity per one cow without subsidies was clearly lower.

Figure 3. Income from Milk Production (Per Dairy Cow) in the Studied Groups of Conventional and Organic Specialised Dairy Farms in 2012

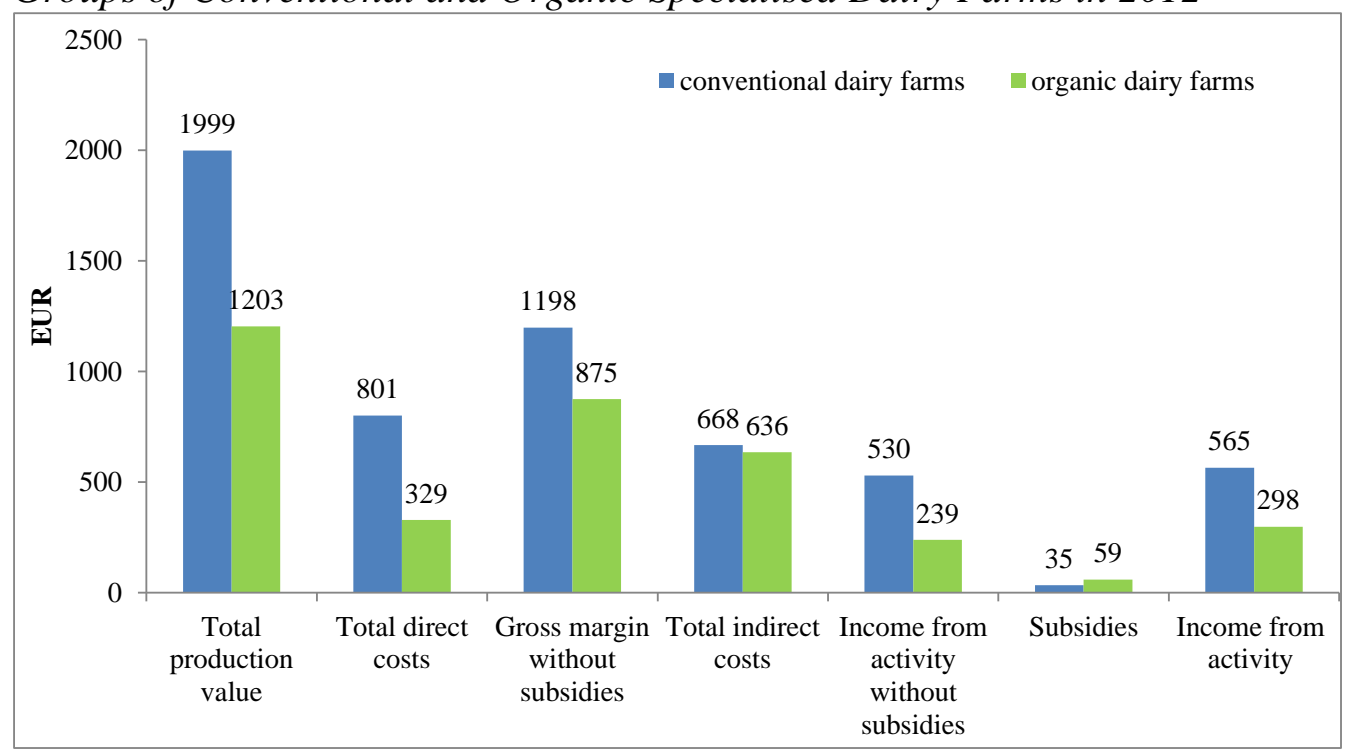

To assess the economic viability of milk production at the researched organic farms, the production profitability index was used, expressed as a percentage ratio of production value to total costs. In the case of researched organic farms, the average production profitability index amounted to $124.8 \%$; while in the group of conventional farms $-136.1 \%$. The weaker result in the case of organic farms was caused by definitely weaker production results.

In order to assess the efficiency of incurred expenses, economic efficiency measures were applied, which confirm the significantly weaker economic results from milk production in organic farms at the level of income from activity - Table 2 . 
Table 2. The Selected Economic Efficiency Measures of Milk Production in Studied Groups of Conventional and Organic Specialised Dairy Farms in 2012

\begin{tabular}{lccc}
\hline \multicolumn{1}{c}{ Specification } & \multicolumn{2}{c}{ Specialised dairy farms } \\
\cline { 3 - 4 } & & conventional & organic \\
\hline Total costs / 1 liter of milk & (EUR) & 0.25 & 0.27 \\
Income from activity without subsidies / 1 liter of milk & (EUR) & 0.09 & 0.07 \\
Own labour input / 1 liter of milk & (hours) & 0.02 & 0.04 \\
Income from activity without subsidies / 1 hour of own labour (EUR) & 4.71 & 1.77 \\
\hline
\end{tabular}

When analysing the results, it is also recommended to take account of the level of income from activity without subsidies per 1 hour of own work. The involvement of own labour inputs in the type of activity 'dairy cows' was relatively high at organic farms (Table 1). Unfortunately, given the rate of parity labour cost in the national economy (in 2012 it was EUR 3.06 per hour), the obtained income from activity (i.e. including the subsidies) did not allow to fully cover the labour of the farmer and his/her family members in the researched group of organic farms - it was covered only in $57.8 \%$. Whereas in the group of conventional farms own labour was covered to the extent of $153.9 \%$.

\section{Conclusions}

It needs to be emphasised that although the production and economic results of milk production of the studied organic farms only reflect the results of the selected sample, there are indications that the level of costs and income to some extent illustrates the performance of organic milk production in general, as these concern average organic farms that keep small herds (16 animals) of dairy cows, where the average milk yields of cows was within the range of 3,580 litres per cow. This points to a highly extensive manner of milk production, even in the case of farms that specialise in milk production. Thus one of the key factors that shape the level of income of these farms is the tendency to lower production costs. However, due to weak production results, this does not translate into a drop in the unit costs of milk production, or into a more efficient use of labour. It should be emphasised that for farmers, maintaining an adequate level of animal welfare is often more important in organic production, as well as meeting the conditions of organic rearing, in case of dairy cows manifested in the longer period of using the cows. Comparing the culling level of cows at the researched organic farms (11.9\%), it may be stated that it was significantly lower than in the researched group of conventional farms, where the culling coefficient amounted to $15.0 \%$ on average.

Organic milk producers, to a large extent, expect to receive relevant premium prices on the produced raw milk. Unfortunately, the analysis of results of the researched farms shows that often the sale prices are lower than 
the average for dairy farms in relatively close neighbourhoods (within the same agricultural region). The main reason for the lack of higher prices for sale of organic milk is still the small number of processing entities interested in organic dairy production. On the other hand, the small scale of milk production at the studied organic farms directly influences the lower level of production value (as compared to conventional production), and it does not allow for negotiating a favourable milk price.

\section{References}

Augustyńska-Grzymek I. et al., 2000, Metodyka liczenia nadwyżki bezpośredniej $i$ zasady typologii gospodarstw rolniczych. FAPA, Warszawa

Mańko S., 2007, Wpływ wielkości stada i wydajności jednostkowej krów na koszty produkcji mleka. Roczniki Nauk Rolniczych. Seria G, Warszawa.

Offermann F., Nieberg H., 2000, Economic Performance of Organic Farms in Europe. Organic Farming in Europe: Economics and Policy. StuttgartHohenheim.

Radkowska I., 2012, Wpływ pastwiskowego systemu utrzymania na dobrostan krów mlecznych, Wiadomości Zootechniczne, Kraków.

Skarżyńska A., 2011, Skala produkcji rolniczych działalności produkcyjnych a ich opłacalność. Roczniki Nauk Rolniczych, SERIA G.

Żukowski K., 2009, Przyczyny wysokiego stopnia brakowania krów mlecznych. Wiadomości Zootechniczne, R. XLVII, 4: 67-86. 
